\title{
Kebijakan Perimbangan Keuangan antara Pemerintah Pusat dan Daerah Pasca Reformasi
}

\author{
Faisal Akbar Nasution \\ Fakultas Hukum Universitas Sumatera Utara \\ Jl. Universitas No. 4 Kampus USU Medan Sumatera Utara \\ faisal@ombudsman.go.id
}

\begin{abstract}
In the post-reform, the establishment of the Law No. 25 year 1999 about the Financial Proportionality between Central Government and Local Government and the Law No. 33 year 2004 about the Financial Proportionality between Central Government and Local Government, Distribution of Proportionality Resources have turned into the distribution of natural resources of local areas. The issue to be analyzed deals with in what financial sector the local areas initiatively find the revenue sources needed to implement their autonomy as a reflection of a decentralization-based implementation as stated in Constitutional of 1945. The method used in the research is based on the judicial-normative approach by applying the materials of primary law, secondary law, and tertiary law. This research additionally applies a normative-qualitative analysis. The establishment of Regulation on the Financial Proportionality in the post of reform shows a very significant outcome for the implementation of autonomy in the local areas. It is due to the local budget is not merely based on the local revenue but, much more than that, the local areas also have the budget resources originated from the local areas alone - that currently is absorbed by the Central Government.
\end{abstract}

Key words : Decentralization, local aoutonomy, local finance, finance balance

\begin{abstract}
Abstrak
Pasca reformasi, lahirnya UU Nomor 25 Tahun 1999 tentang Perimbangan Keuangan antara Pemerintahan Pusat dan Daerah dan UU Nomor 33 Tahun 2004 tentang Perimbangan Keuangan antara Pemerintah Pusat dan Pemerintah Daerah, pembagian sumber-sumber perimbangan telah bergeser kepada pembagian beberapa sumber daya alam yang berada di daerah-daerah. Permasalahan yang diteliti adalah pada sektor keuangan mana daerah-daerah dapat berinisiatif mencari sumber-sumber penerimaan yang dibutuhkan untuk melaksanakan otonominya sebagai pencerminan pelaksanaan asas desentralisasi seperti yang dianut UUD 1945 ? Metode penelitian yang digunakan pendekatan yuridis normatif, dengan menggunakan bahan-bahan hukum primer, bahan hukum sekunder dan bahan hukum tertier, dan analisis yang dilakukan bersifat normatif kualitatatif. Dengan lahirnya undang-undang perimbangan keuangan pasca reformasi, menunjukkan hasil yang signifikan bagi pelaksanaan otonomi daerah itu, karena sumber-sumber pembiayaan daerah tidak lagi hanya didasarkan kepada hasil-hasil PAD semata tetapi daerah-daerah juga memiliki sumber pembiayaan lainnya yang berasal dari daerah-daerah itu sendiri yang selama ini hanya dinikmati oleh pemerintah pusat.
\end{abstract}

Kata kunci : Desentralisasi, otonomi daerah, keuangan daerah, perimbangan keuangan 


\section{Pendahuluan}

Keuangan merupakan faktor penting dalam suatu negara, dikarenakan pengaruhnya yang demikian menentukan terhadap kompleksitas kelangsungan hidup negara dan masyarakatnya. Pengaruh dari aspek keuangan negara antara lain juga mencerminkan kualitas keberadaan dari suatu pemerintahan dalam menjalankan fungsi-fungsi kenegaraannya.

Apabila sumber pendanaan dari keuangan negara yang dimiliki semakin baik, maka kedudukan Pemerintah di dalam menjalankan keorganisasian negara, baik dalam rangka melaksanakan urusan-urusan pemerintah dan pembangunan maupun pelayanan terhadap warganya akan bertambah stabil dan semakin baik serta positif di mata rakyatnya. Sebaliknya, suatu pemerintahan dipandang akan menghadapi berbagai problema pelik dalam memperlancar pelaksanaan segenap fungsi dan tugas kenegaraan, jika tidak didukung kondisi keuangan negara yang baik pula.

Mengingat eksistensi keuangan demikian vital bagi suatu negara, maka segala daya upaya akan dilakukan oleh Pemerintah untuk menciptakan dan memanfaatkan segenap sumber keuangan yang ada. Hasil-hasil yang diperoleh selanjutnya akan dipergunakan untuk membiayai pengeluaran kegiatan jalannya pemerintahan dan pembangunan. Sebagian besar hasil penerimaan yang diperoleh dari upaya pemanfaatan segenap potensi keuangan yang berhasil diterima oleh Pemerintah Pusat, disalurkan dan digunakan melalui sektor-sektor yang ditentukan dalam APBN.

\section{Rumusan Masalah}

Permasalahan yang menarik untuk dikaji dalam penelitan ini adalah, pada sektor keuangan mana daerah-daerah dapat berinisiatif mencari sumber-sumber penerimaan yang dibutuhkan untuk melaksanakan otonominya sebagai pencerminan pelaksanaan asas dsentralisasi seperti yang dianut berdasarkan ketentuan UUD 1945 ?

\section{Tujuan Penelitian}

Penelitian ini ditujukan untuk mengkaji dan menemukan kebijakan pengaturan hubungan keuangan antara pusat dan daerah yang bagaimanakah yang dapat mencerminkan keadilan dan kepastian dalam pembagian sumber-sumber 
pendapatan antara pusat dengan daerah-daerah. Sehingga daerah-daerah tidak perlu lagi mempunyai ketergantungan yang kuat kepada kebijakan pemerintah pusat dalam hal pembiayaan keuangan daerahnya.

\section{Metode Penelitian}

Metode penelitian dalam tulisan ini mempergunakan pendekatan yuridis normatif, dengan menggunakan bahan-bahan hukum primer, bahan hukum sekunder dan bahan hukum tertier, dan analisis yang dilakukan bersifat normatif kualitataif.

\section{Hasil dan Pembahasan}

\section{Hubungan Keuangan Negara dengan Keuangan Daerah}

Salah satu konsekuensi bagi negara Indonesia dalam menganut faham negara yang bersusunan kesatuan yang didesentralisir adalah, terjadinya hubungan keuangan antara pemerintah pusat dengan pemerintah daerahnya. Hal ini berarti dibutuhkan adanya suatu sistem (pola) tertentu untuk membagi-bagikan kewenangan dibidang keuangan antara pusat dengan daerah-daerah, sebagaimana dikatakan oleh N. Arsyad, yaitu suatu sistem yang mengatur bagaimana caranya sejumlah dana dibagi antar pelbagai tingkat pemerintahan untuk menunjang kegiatan-kegiatan sektor publik pada berbagai macam tingkatan. Sistem ini juga mengatur bagaimana caranya mencari sumber-sumber pembiayaannya, ${ }^{1}$ yang pada gilirannya akan melahirkan apa yang dikenal dengan sebutan desentralisasi fiskal sebagai suatu keharusan untuk menjaga keharmonisan hubungan antara kedua tingkatan pemerintahan berdasarkan UUD 1945. Hal ini dimaksudkan agar selain pusat mempunyai sumber-sumber pendapatannya sendiri, melalui kebijakan desentralisasi fiskal ini daerah-daerah juga diharapkan memiliki kepastian untuk mendapatkan penerimaan dari sumber yang berbeda, sehingga tidak terlalu tergantung sama sekali dengan sumber-sumber keuangan pemerintah pusat, yang

${ }^{1}$ N. Arsyad sebagaimana dikutip dalam Alfitra Salamm dan Kurniawati Hastuti Dewi (editor), Dinamika Hubungan Kenangan Pusat - Daerah, Perspektif Politik Lokal, (Jakarta, Pusat Penelitian Lembaga Ilmu Pengetahuan Indonesia (P2P-LIPI), 2001), hlm. 2 
dapat menghilangkan eksistensi otonomi yang dimilikinya. Roger Stacey dan John Oliver dalam buku bersama mereka, ${ }^{2}$ menegaskan bahwa sekalipun perihal keuangan negara diatur dan berada pada kekuasaan negara secara mutlak, namun pembagian pengaturannya di daerah tetap menjadi hal yang niscaya dilakukan. .

Hubungan keuangan antara pusat dengan daerah dapat ditinjau dari ketentuan Undang-undang yang menyerahkan beberapa jenis pajak dan retribusi negara untuk menjadi pajak dan retribusi daerah. Pada umumnya sumber pemajakan dan retribusi yang diserahkan itu mempunyai dasar pengenaan dan objek serta subjek pajak dan retribusi yang berada dan berkaitan dengan daerah itu sendiri.

Penyerahan beberapa jenis pajak dan retribusi daerah itu, berdasarkan ketentuan Undang-undang yang pernah dikeluarkan Pemerintah Pusat adalah UU Darurat Nomor 11 Tahun 1957 tentang Pajak Daerah dan UU Darurat Nomor 12 Tahun 1957 tentang Retribusi Daerah, ${ }^{3}$ yang kemudian setelah sekian puluh tahun dan diikuti dengan beberapa kali pergantian Undang-undang Pemerintahan Daerah sebagai ketentuan pokoknya, ${ }^{4}$ maka pada tahun 1997 dikeluarkanlah UU Nomor 18 Tahun 1997 tentang Pajak Daerah dan Retribusi Daerah, ${ }^{5}$ kemudian setelah keluarnya UU Nomor 22 Tahun 1999, undang-undang ini direvisi menjadi UU Nomor 34 Tahun 2000 tentang Perubahan atas Undang-undang Nomor 18 Tahun 1997 tentang Pajak Daerah dan Retribusi Daerah, dan terakhir dengan landasan UU Nomor 32 Tahun 2004 yang telah mengalami perubahan sebanyak 2 (dua) kali dan terakhir dengan UU Nomor 12 Tahun 2008 keluar UU Nomor 28 Tahun 2009 tentang Pajak Daerah dan Retribusi Daerah.

Hubungan keuangan antara Pemerintah Pusat dengan Pemerintah Daerah dimasa lalu juga terlihat dari adanya kebijakan berupa pemberian bantuan selain

\footnotetext{
${ }^{2}$ Roger Stacey dan John Oliver, Public Administration; The Political Environment, (Great Britain, Mac Donald \& Evans Ltd, 1980), hlm. 196.

${ }^{3}$ Kedua Undang-undang ini adalah didasarkan kepada ketentuan UU Nomor 1 Tahun 1957 yang diterbitkan oleh Pemerintah Pusat dengan didasarkan kepada ketentuan-ketentuan UUD Sementara Tahun 1950, khususnya pada ketentuan Pasal 131 sampai dengan 133 UUDS 1950.

${ }^{4}$ Undang-undang dimaksud adalah Penetapan Presiden (Penpres) Nomor 6 Tahun 1959 tentang Pemerintahan Daerah yang diikuti dengan Penpres Nomor 5 Tahun 1960 tentang DPRD Gotong Royong. Selanjutnya keluar UU Nomor 18 Tahun 1965 tentang Pokok-pokok Pemerintahan Daerah, yang kemudian diganti dengan UU Nomor 5 Tahun 1974 tentang Pokok-pokok Pemerintahan di Daerah. Akhirnya setelah tumbangnya rezim orde baru keluarlah UU Nomor 22 Tahun 1999 dan kemudian digantikan dengan Undang-undang yang terakhir yang mengatur tentang pemerintahan daerah ini yakni UU Nomor 32 Tahun 2004. Kesemua Penpres dan Undang-undang diatas adalah didasarkan kepada ketentuan UUD 1945 yang berlaku kembali sejak keluarnya Dekrit Presiden 5 Juli 1959.

${ }^{5}$ Undang-undang ini adalah merupakan derivasi dari ketentuan yang terdapat di dalam UU Nomor 5 Tahun 1974 tentang Pokok-pokok Pemerintahan di Daerah, dimana di dalam salah satu pasalnya yaitu Pasal 56 menyebutkan bahwa "dengan Undang-undang sesuatu pajak negara dapat diserahkan kepada Daerah"
} 
subsidi. Misalnya berupa bantuan pembangunan berbentuk Intruksi Presiden (Inpres-inpres) sebagai implementasi dari tugas pembantuan (medebewind) yang dilaksanakan oleh setiap pemerintah daerah, bagi hasil beberapa pajak pusat seperti pajak bumi dan bangunan (PBB) dan iurah hasil hutan, subsidi bahan bakar minyak (BBM), serta sumbangan rehabilitasi cengkeh, kopra, dan lain sebagainya.

Pemberian bantuan kepada setiap pemerintah daerah ini tiada lain dimaksudkan untuk melakukan pemerataan pembangunan antardaerah, supaya ketimpangan diantara daerah yang kaya akan sumber daya alam dan daerah yang miskin potensinya dapat dihapus atau setidak-tidaknya dapat dikurangi. Selain itu, pemberian bantuan juga dimaksudkan sebagai pendorong bagi perkembangan otonomi dan keinisiatifan daerah menggali potensi daerahnya lebih maksimal dalam rangka meningkatkan sumber-sumber pendapatan asli daerahnya.

Meski kebijakan bantuan cukup membawa dampak positip bagi perkembangan daerah-daerah di Indonesia kala itu, namun sulit pula disangkal bahwa kebijakan ini dapat pula menimbulkan konsekuensi yang pelik bagi kelangsungan penyelenggaraan pemerintahan daerah. Konsekuensi pelik yang dimaksud ialah terjadinya ketergantungan daerah yang begitu kuat dan besar kepada pemerintah pusat akan sumber-sumber keuangan. Hal ini pada gilirannya tidak saja akan mengurangi gairah dan inisiatif daerah untuk menggali sumber pendapatan asli daerahnya secara lebih maksimal, tetapi juga mempengaruhi praktek kebijakan pemberian otonomi kepada daerah-daerah. Sebab bukankah dengan pemberian otonomi itu, membuat daerah seharusnya menjadi mampu untuk menutupi kebutuhan-kebutuhannya sendiri di dalam melayani masyarakat daerahnya baik dalam pelayanan publik maupun pembangunan, atau dengan perkataan lain akan mampu membelanjai dirinya sendiri tanpa terlalu tergantung sama sekali kepada belas kasihan pemerintah pusat. ${ }^{6}$

Berdasarkan hal-hal tersebut di atas, patut disambut gembira dengan lahirnya kebijakan otonomi daerah sebagai pelaksanaan UU Nomor 22 Tahun 1999 dan UU Nomor 25 Tahun 1999 yang mulai dijalankan sejak bulan Januari 2001, yang memasukkan dana berbagai subisidi (seperti SDO) dan dana-dana Inpres dikelompokkan kedalam satu point yaitu dana alokasi umum (DAU) yang

${ }^{6}$ Lihat Bagir Manan, Hubungan antara Pusat dan Daerah Berdasarkan Asas Desentralisasi Menurut UUD 1945, Disertasi, Universitas Padjajaran, Bandung, 1990, hlm. 314. 
merupakan salah satu komponen dari dana perimbangan keuangan pusat dan daerah sebagaimana ditetapkan dalam UU Nomr 25 Tahun 1999,7 yang kemudian kebijakan yang sama diteruskan oleh pengganti kedua undang-undang pemerintahan daerah diatas dengan UU Nomor 32 Tahun 2004 dan UU Nomor 33 Tahun 2004 seperti telah disinggung dimuka.

\section{Kebijakan Pengaturan Perimbangan Keuangan antara Pemerintah Pusat dan Daerah Menurut UU Nomor 25 Tahun 1999}

Guna menjalankan kewajiban dalam melaksanakan otonominya, dan sebagai bagian dari pendistribusian penyelenggaraan kekuasaan pemerintahan negara, maka daerah-daerah memerlukan sumber-sumber pembiayaan yang memadai dan cukup. Dalam melaksanakan otonominya tersebut, oleh pemerintah pusat kepada daerahdaerah telah diberikan berbagai sumber pembiayaan guna menopang pelaksanaan otonomi tersebut, diantaranya adalah berupa pendapatan asli daerah (PAD) sebagai sumber pembiayaan yang utama dan diharapkan akan mampu untuk membiayai segala pembiayaan pelaksanaan otonomi daerah itu. Namun disadari karena keterbatasan sumber daya yang dapat dihandalkan pada setiap daerah guna menghasilkan PAD-nya, maka pelaksanaan otonomi daerah tersebut tidaklah berimplikasi kepada keharusan bagi setiap daerah untuk menutupi segala pembiayaan jalannya pemerintahan daerah itu secara penuh harus dibiayai dari sumber PAD-nya. Dalam keadaan seperti ini, kewajiban pemerintah pusat untuk memberikan transfer sumber-sumber pembiayaan lainnya kepada daerah menjadi suatu keharusan. Dalam konteks inilah kebijakan desentralisasi fiskal ${ }^{8}$ merupakan

\footnotetext{
${ }^{7}$ Bachrul Elmi, Kenangan Pemerintah Daerah Otonom di Indonesia, (Jakarta, UI Press, 2002), hlm. 25.

${ }^{8}$ Desentralisasi fiskal menurut studi Bank Dunia yang dilakukan oleh Rondinelli adalah merupakan komponen utama dari desentralisasi, yang mencakup : (1) Self financing atau cost recovery dalam pelayanan publik terutama melalui pengenaan retribusi daerah, (2) Cofinancing atau coproduction dimana pengguna jasa publik berpartisipasi dalam bentuk pembayaran jasa atau kontribusi tenaga kerja (3) Peningkatan PAD melalui penambahan kewenangan pengenaan pajak daerah terutama pajak property (PBB), pajak penjualan (PPn), pajak penghasilan perseorangan $(\mathrm{PPh}$ orang pribadi) atau berbagai jasa retribusi daerah, (4) Transfer dari pemerintah pusat terutama berasal dari sumbangan umum (DAU), sumbangan khusus (DAK), sumbangan darurat (Dana darurat), dan bagi hasil pajak dan bukan pajak, dan (5) Kebebasan daerah untuk melakukan pinjaman. Lihat Machfud Sidik dalam Madyagama et al (editor), Bunga Rampai Desentralisasi Fiskal, Jakarta, Direktorat Jenderal Perimbangan Keuangan Pusat dan Daerah Departemen Keuangan RI, 2004), hlm. 3 - 4. Machfud Sidik sendiri mengartikan desentralisasi fiskal itu sebagai sebuah kebijakan pemerintah pusat untuk mendukung penyelenggaraan otonomi daerah yang luas, nyata, dan bertanggung jawab, dimana kepada daerah diberikan : (1) kewenangan untuk mendayagunakan sumber keuangan sendiri dan didukung dengan (2) perimbangan keuangan antara Pusat dan Daerah. Lihat Machfud Sidik, "Kebijakan Perimbangan Keuangan Pusat dan Daerah di Era Otonomi Daerah", Makalah yang disampaikan pada kuliah perdana Program Pascasarjana FISI-UI Jakarta, tanggal 27 Agustus 2001, hlm. 26
} 
solusi bagi pemerintah pusat dan daerah untuk sama-sama memanfaatkan sumber keuangan yang dapat digali dalam batas-batas wilayah negara Indonesia untuk dimanfaatkan dan dibagi secara proporsional dan rasional diantara kedua tingkatan pemerintahan tersebut.

Praktik pembiayaan pemerintahan daerah selama ini yang tidak mampu hanya mengandalkan PAD, karena masih relatif sangat kecil untuk membiayai jalannya otonomi daerah menyebabkan penerimaan pemerintah daerah sangat tergantung kepada transfer dana dari pemerintah pusat. Agar pemberian sumber-sumber pembiayaan dari pemerintah pusat ini jangan dianggap sebagai belas kasihan dari pusat kepada daerah, maka harus dibangun suatu kesadaran bahwa ketika pemerintah pusat memperoleh sumber-sumber penerimaannya pun sesungguhnya juga berasal dari sumber-sumber yang terdapat di masing-masing daerah. Dalam kerangka seperti inilah suatu perimbangan keuangan diantara pemerintah pusat dengan pemerintah daerah merupakan suatu keniscayaan, agar bandul kelangsungan prinsip negara kesatuan Republik Indonesia tetap terjaga dan eksis sepanjang masa. Hal ini sejalan dengan pemikiran yang berkembang bahwa prinsip diberikannya otonomi kepada daerah selain memberi wewenang kepada daerah untuk mengurus daerahnya dengan mengandalkan sebagian besar pembiayaan dari sumber keuangannya sendiri, juga mempunyai hak untuk mendapatkan bantuan dari pemerintah pusat yang memperoleh sumber-sumber penerimaannya justru berasal dari daerah-daerah, sesuai dengan kemampuan pemerintah pusat (prinsip dari negara kesatuan).

Adanya pembagian sumber keuangan antara pemerintah pusat dengan daerah, berimplikasi akan memberikan kepastian bagi daerah-daerah untuk dapat menjalankan otonominya dengan tidak sekedar hanya mengandalkan sumber pembiayaan dari segi PAD-nya saja, yang ditengarai tidak mencukupi kebutuhan fiskal (fiscal needs) bagi pemerintah daerah untuk membiayai tugas-tugas otonominya. Hal ini disebabkan banyak sumber-sumber penerimaan yang termasuk katagori PAD pada umumnya bukan merupakan sumber yang potensial bagi daerah, dimana sumber yang potensial tersebut sudah diambil sebagai sumber penerimaan pemerintah pusat. Tetapi di samping itu juga ditambah dengan transfer dana dari pemerintah pusat yang menjadi bagian atau hak dari pemerintah daerah tersebut. Dengan demikian lahirnya kebijakan perimbangan keuangan ini mengandung maksud bahwa kepada daerah akan diberikan kewenangan untuk 
selain memanfaatkan sumber keuangan sendiri juga didukung dengan perimbangan keuangan yang proporsional dan adil diantara kedua tingkatan pemerintahan tersebut. Adapun yang menjadi tujuan kebijakan perimbangan keuangan yang dilakukan pemerintah pusat ini, menurut pandangan Bachrul Elmi ${ }^{9}$ adalah : 1. dalam rangka pemberdayaan (empowerment) masyarakat dan pemerintah daerah yang selama ini tertinggal di bidang pembangunan, 2. untuk mengintensifkan aktivitas dan kreativitas perekonomian masyarakat daerah yang berbasis pada potensi yang dimiliki masing-masing daerah. Pemerintah daerah dan Dewan Perwakilan Rakyat Daerah (DPRD) bertindak sebagai fasilitator dalam pembangunan ekonomi yang dilakukan oleh rakyatnya. Artinya dalam era otonomi daerah, rakyat dan masyarakat harus berperan aktif dalam perencanaan dan pelaksanaan pembangunan daerahnya, 3. mendukung terwujudnya good governance oleh pemerintah daerah melalui perimbangan keuangan yang transparan, 4 . untuk menyelenggarakan otonomi daerah secara demokratis, efektif dan efisien, dibutuhkan sumber daya manusia (SDM) yang profesional serta memiliki ahlak atau moral yang baik. Oleh sebab itu desentralisasi fiskal yang dilaksanakan melalui perimbangan keuangan akan meningkatkan kemampuan daerah untuk membangun dan meningkatkan pemberian pelayanan kepada masyarakat daerah, artinya bukan sekedar pembagian dana, lalu memindahkan korupsi, kolusi dan nepotisme (KKN) dari pusat ke daerah.

Lahirnya UU Nomor 25 Tahun 1999 yang menggantikan UU Nomor 32 Tahun 1956 dapat dianggap merupakan kebijakan legislatif nasional yang telah merubah secara mendasar sistem perimbangan keuangan seperti yang dipraktekkan selama berlangsungnya UU Nomor 32 Tahun 1956 yang lebih cenderung bersifat sentralistis terlebih-lebih semasa pemerintahan rezim orde baru, menuju sebuah sistem keuangan daerah yang lebih adil dan aspiratif bagi penerimaan sumber-sumber keuangan daerah yang pasti dan jelas bagi pemerintah daerah. Kebijakan baru ini tidak saja mengatur tentang desentralisasi fiskal, tetapi juga bagaimana daerah-daerah memiliki keleluasaan dalam menggunakan sumber-sumber penerimaannya termasuk dari hasil transfer dana dari pihak pemerintah pusat, tanpa adanya arahan-arahan terhadap penggunaannya seperti lazim di dalam praktek pada masa yang lalu.

Bila pengaturan perimbangan keuangan pada masa lalu di bawah UU Nomor 32 Tahun 1956 menimbulkan masalah, yakni kekaburan pembagian wewenang

${ }^{9}$ Bachrul Elmi, Op.Cit, hlm. 54 - 55 
melaksanakan urusan-urusan pemerintahan antara pusat dan daerah, yang berimplikasi juga terhadap kesimpangsiuran dan ketidakpastian dari segi pembiayaan terutama bagi pemerintah daerah, serta pelaksanaan pengawasan dan tanggung jawab dari kegiatan pada semua sektor tingkat pemerintahan saling tumpang tindih, maka hal tersebut diharapkan tidak dijumpai lagi dengan munculnya era otonomi daerah yang dibidani oleh UU Nomor 22 Tahun 1999 dan UU Nomor 25 Tahun 1999.

Berdasarkan UU Nomor 25 Tahun 1999 ini, daerah-daerah berhak mendapatkan sumber penerimaan dari pemerintah pusat yang menyangkut penerimaan pemerintah pusat yang berasal dari daerah, berupa bagi hasil pajak, pengelolaan sumber daya alam (SDA) yang terdapat pada masing-masing daerah, serta bantuan berupa dana alokasi umum dan Dana Alokasi Khusus (DAK) sebagai bagian terpenting dari politik/kebijakan perimbangan keuangan antar tingkat pemerintahan tersebut.

Adapun rincian sumber penerimaan daerah dari hasil perimbangan keuangan ini berdasarkan UU Nomor 25 Tahun 1999 dan PP Nomor 104 Tahun 2000 tentang Dana Perimbangan adalah sebagai berikut : 1 . bagian daerah dari penerimaan pajak bumi dan bangunan dan bea perolehan hak atas tanah dan bangunan (BPHTB), yang selanjutnya dibagi menurut imbangan sebagai berikut : a. penerimaan dari pajak bumi dan bangunan: untuk pemerintah pusat sebesar $10 \%$ dan $90 \%$ untuk pemerintah daerah; dan b. penerimaan dari bea perolehan hak atas tanah dan bangunan (BPHTB): Untuk pemerintah pusat sebesar $20 \%$ sedangkan $80 \%$ untuk daerah. 2. penerimaan dari beberapa SDA yang terdapat di daerah, yang terdiri dari a. penerimaan dari iuran hak pengusahaan hutan (IHPH): $20 \%$ untuk pemerintah pusat sedangkan sisanya $80 \%$ untuk daerah; b. penerimaan dari provisi sumber daya hutan (PSDH): Untuk pemerintah pusat sebesar $20 \%$, sedangkan untuk daerah sebesar $80 \%$; c. penerimaan dari iuran tetap pertambangan umum (landrent) sebesar $20 \%$ untuk pemerintah pusat dan $80 \%$ buat daerah; d. penerimaan dari iuran eksplorasi dan iuran eksloitasi pertambangan umum (royalty pertambangan umum): sebesar $20 \%$ untuk pemerintah pusat dan untuk daerah sebesar $80 \%$; e. penerimaan dari hasil pungutan pengusahaan perikanan dan pungutan hasil perikanan, dibagi antara $20 \%$ untuk pemerintah pusat dan sisanya $80 \%$ dibagikan secara merata kepada seluruh kabupaten/kota di Indonesia; f. penerimaan dari hasil pertambangan minyak (setelah dikurangi komponen pajak), dibagi antara pemerintah pusat yang memperoleh $85 \%$ dengan sisanya $15 \%$ untuk daerah; g. penerimaan dari 
pertambangan gas alam (setelah dikurangi komponen pajak), dibagi untuk $70 \%$ buat pemerintah pusat dan $30 \%$ buat daerah; dan $h$. penerimaan dari dana reboisasi, yang dibagi antara $60 \%$ untuk pemerintah pusat yang digunakan untuk pembiayaan kegiatan reboisasi secara nasional, dan 40 \% diberikan kepada daerah penghasil melalui dana alokasi khusus yang digunakan untuk pembiayaan kegiatan reboisasi dan penghijaun di daerah penghasil yang bersangkutan.

Selanjutnya dengan lahirnya UU Nomor 17 Tahun 2000 tentang Perubahan Ketiga atas Undang-Undang Nomor 7 Tahun 1983 tentang Pajak Penghasilan, ${ }^{10}$ dimana ditentukan untuk penerimaan negara dari hasil pajak negara (yaitu pajak penghasilan perorangan ini) yang dikutip oleh pemerintah pusat selanjutnya dibagi untuk penerimaan pemerintah pusat sebesar $80 \%$ sedangkan sisanya $20 \%$ dibagi antardaerah, dimana untuk propinsi menerima $8 \%$ dan $12 \%$ lagi untuk kabupaten/kota.

Berkaitan dengan terjadinya perubahan kenaikan pendapatan daerah dari sektor perimbangan keuangan ini, mengindikasikan terjadinya beberapa perubahan yang sangat mendasar dalam pelaksanaan UU Nomor 25 Tahun 1999 ini yang akan berimplikasi kepada posisi keuangan daerah. Beberapa perubahan itu seperti yang dikatakan oleh Alfitra Salamm ${ }^{11}$ diantaranya adalah penetapan prosentase bagi hasil yang jelas untuk PBB, BPHTB dan sumber daya alam dari sektor kehutanan, perikanan, minyak, mineral dan gas alam (dana perimbangan), dan plafon jumlah DAU yang akan dibagikan ke daerah dan DAK seperti yang diatur dalam PP Nomor 104 Tahun 2000 tentang Perimbangan Keuangan, yang dapat menjadi salah satu alternatif sumber pendapatan daerah yang berasal dari pemerintah pusat dengan landasan yuridis yang tegas dan menjamin daerah-daerah secara pasti untuk memperoleh haknya yang berasal dari sumber penerimaan pemerintah pusat. Di samping itu bila dilihat dari segi pengambilan keputusan penggunaan keuangan daerah seperti diatur dalam undang-undang ini memberikan kemajuan jika dibandingkan dengan masa-masa sebelumnya yang selalu diarahkan oleh pemerintah pusat. Pada masa sekarang ini pemerintah daerah mempunyai

${ }^{10}$ Ditetapkannya Pajak Penghasilan (PPh) perseorangan ini sebagai obyek hasil pajak negara yang dibagihasilkan oleh pemerintah pusat kepada pemerintah daerah adalah dimaksudkan sebagai kompensasi dan penyelaras bagi daerahdaerah yang tidak memiliki sumber daya alam (SDA) namun telah memberikan kontribusi yang besar bagi penerimaan negara (APBN), seperti misalnya Propinsi DKI Jakarta.

${ }^{11}$ Alfitra Salamm, Otonomi Daerah dan Akuntabilitas Perimbangan Keuangan Pusat - Daerah, Makalah pada Workshop Desentralisasi, Demokratisasi, dan Akuntabilitas Pemerintahan Daerah, yang diselengarakan oleh AIPI bekerja sama dengan Partnership for Governance Reform in Indonesia dan Universitas Diponegoro pada bulan Maret 2020 di Semarang. 
keleluasaan untuk mengatur dan merencanakan penggunaan keuangan daerah sesuai dengan kebijakan yang ditetapkan masing-masing pemerintah daerah, termasuk penggunaan dari dana-dana perimbangan (bagi hasil, dana alokasi umum, dan dana alokasi khusus) karena lebih bersifat block grant yang akan memberikan kekebasan bagi masing-masing daerah.

Dengan kejelasan pembagian hasil dari perimbangan keuangan ini pada gilirannya akan membawa dampak positip bagi masing-masing daerah dalam melaksanakan otonomi yang menjadi tanggungjawabnya, dengan demikian apa yang menjadi tujuan diberikannya otonomi daerah yang nyata dan seluas-luasnya yang dikembangkan dalam undang-undang pemerintahan daerah (UU Nomor 22 Tahun 1999) yang menggantikan UU Nomor 5 Tahun 1974 mulai menunjukkan kenyataan terdapatnya perubahan konsep dalam pengurusan jalannya pemerintahan antara pemerintah pusat di satu pihak dengan pemerintah daerah di lain pihak, yang dalam hal ini telah menggeser paradigma pemerintahan yang tadinya cenderung bersifat sentralistis ke arah desentralisasi.

Meskipun kelahiran UU Nomor 25 Tahun 1999 telah memberikan masukan sumber pendapatan daerah yang cukup siginifikan terhadap anggaran daerah (APBD) yang akan berpengaruh besar bagi jalannya otonomi daerah pada masingmasing daerah, dimana secara umum pemerintah-pemerintah daerah baik Kabupaten dan Kota maupun Propinsi mulai menikmati guyuran sumber penerimaan yang amat besar melalui pendistribusian dana perimbangan yang diatur dalam Undang-undang ini yang selanjutnya diimplementasikan dalam PP Nomor 104 Tahun 2000 dibandingkan sebelum lahirnya undang-undang ini. Namun dalam pelaksanaannya masih juga menimbulkan perasaan ketidakadilan bagi beberapa daerah, terutama daerah-daerah yang tidak memiliki atau miskin akan sumber kekayaan alam yang menjadi dasar pembagian perimbangan keuangan seperti diatur dalam kedua peraturan perundang-undangan di atas, tetapi secara ekonomis daerahdaerah ini telah memberikan kontribusi yang tidak kecil pula bagi penerimaan negara (APBN). Kasus Propinsi Jawa Timur misalnya, menurut hasil penelitian dari Tim Lembaga Ilmu Pengetahuan Indonesia (LIPI) yang dilakukan oleh Kurniawati Hastuti Dewi, ${ }^{12}$ bahwa Propinsi ini pada tahun 1996 telah menyumbangkan sekitar

${ }^{12}$ Kurniawati Hastuti Dewi dalam Alfitra Salamm dan Kurniawati Hastuti Dewi (editor) : Dinamika Hubungan Kenangan Ousat - Daerah, Perspektif Lokal, P2P-LIPI, Jakarta, 2001, hlm. 93 - 107. 
Rp. 77.000.000.000.000,00 produk domestik regional bruto (PDRB) dari total PDB Nasional sebesar Rp. 532.000.000.000.000,00. Ini berarti Jawa Timur merupakan kontributor PDRB ketiga terbesar bagi PDB Nasional setelah Jawa Barat (Rp. 88.400.000.000.000,00) dan DKI Jakarta (Rp. 82.000.000.000.000,00), dan sekitar 4 sd 5 triliun rupiah uang yang berasal dari Propinsi ini tersedot ke Jakarta (Pemerintah Pusat) setiap tahunnya untuk mengisi penerimaan APBN yang disumbangkan melalui penghasilan cukai rokok, tembakau, dan minuman keras, belum lagi termasuk PPh dan PPn yang berasal dari industri semen dan petrokimia di Gresik dan industri elektronika yang berada di Surabaya. Pihak Pemerintah Propinsi maupun Kabupaten dan Kota yang terdapat di Jawa Timur sama sekali tidak memperoleh manfaat apapun kecuali dari PBB. Padahal kerugian lingkungan atau dampak negatif yang mungkin terjadi akan dirasakan langsung oleh daerah yang bersangkutan. Sehingga bagi Propinsi Jawa Timur dimasukkannya pajak pendapatan tidak langsung dari industri jasa (PPn, cukai, bea masuk, pajak ekspor) ke dalam dana perimbangan yang dapat dibagihasilkan merupakan sesuatu harapan yang harus didengar oleh pemerintah pusat. Hal yang sama terjadi pula pada beberapa daerah propinsi lainnya yang memiliki potensi sumber daya ekonomis terutama yang berasal dari sektor indusrti dan jasa seperti Propinsi Sumatera Barat yang memiliki 2 (dua) indusrti besar yaitu industri semen padang di Indarung dan pertambangan batubara di Ombilin yang dikuasai oleh Pemerintah Pusat. ${ }^{13}$

Kasus yang menimbulkan ketidakadilan pembagian dana perimbangan dan bahkan dapat menimbulkan silang sengketa atau konflik antardaerah di dalam praktek UU Nomor 22 Tahun 1999 bukan saja terjadi pada daerah-daerah miskin akan sumber daya alam, tetapi dapat pula terjadi pada daerah yang memiliki sumber kekayaan alam yang melimpah seperti terjadi di Propinsi Kalimantan Timur. Propinsi ini yang dianugerahi dengan limpahan sumber kekayaan yang tak terkira berupa minyak dan gas alam, serta dari hasil kehutanan, setelah era otonomi daerah diberlakukan memang relatif sangat besar sekali menerima dana perimbangan bila dibandingkan dengan masa-masa sebelumnya. Hal ini tercermin dalam nilai total perolehan DAU dan dana bagi hasil yang diperoleh Propinsi Kalimantan Timur dan Kabupaten-kabupaten serta Kota-kota se Kalimantan Timur yang jumlahnya mencapai sekitar Rp. 6.100.000.000.000,00. Padahal pada tahun 1999 sebelum paket

${ }^{13}$ Lihat Syamsunar Dam dalam Alfitra Salamm dan Kurniawati Hastuti (editor), Ibid, hlm. 118 - 122. 
kebijakan otonomi daerah diimplementasikan, melalui instrumen subsidi dari Pemerintah Pusat, Kalimantan Timur hanya memperoleh sekitar Rp. 1.200.000.000.000,00 atau 2,1 \% dari PDRB Propinsi tersebut. ${ }^{14}$

Menurut anggota Tim peneliti LIPI Syamsuddin Haris ${ }^{15}$ yang melakukan penelitian di Propinsi Kalimantan Timur, meskipun Propinsi ini memperoleh distribusi perimbangan keuangan dari pemerintah pusat yang relatif besar, bukan berarti hubungan keuangan pusat - daerah yang diatur melalui UU Nomor 25 Tahun 1999 ini tanpa masalah. Beberapa pejabat Pemerintah Daerah Kalimantan Timur menurut hasil penelitiannya, mengemukakan kekecewaan mereka terhadap cara perhitungan dana perimbangan yang diperoleh daerah-daerah, khususnya daerah penghasil SDA. Mereka mempersoalkan cara perhitungan pemerintah pusat dalam mendistribusikan dana bagi hasil SDA yang kemudian memicu munculnya konflik antardaerah seperti yang terjadi di Kalimantan Timur. Ironisnya dalam praktik departemen-departemen teknis di Jakarta, seperti Departemen Keuangan, Departemen Pertambangan dan Energi, dan juga Departemen Kehutanan, merumuskan kebijakan perhitungan yang berbeda-beda, sehingga muncul kesan bahwa pemerintah pusat sendiri belum mampu melakukan koordinasi yang baik dalam mengimplementasikan kebijakan otonomi daerah tersebut. Dalam kaitan ini pemerintah pusat tidak pernah memperhitungkan dan mengantisipasi kemungkinan munculnya konflik yang bersifat multidimensi di daerah sebagai akibat inkonsistensi dalam implementasi kebijakan yang dilakukan oleh para pejabat pemerintah pusat. Akibatnya, muncul kecenderungan untuk melakukan penafsiran secara sepihak atas paket kebijakan yang ada sesuai dengan kebutuhan dan kepentingan masing-masing pihak di Pusat maupun di Daerah.

Bila bercermin dari beberapa contoh kasus di atas, baik pada kasus Propinsi Jawa Timur maupun Propinsi Kalimantan Timur, permasalahan yang menonjol dan sekaligus perbedaan yang mendasar pengaturan dana bagi hasil perimbangan seperti diatur dalam UU Nomor 22 Tahun 1999 yang mengatur perimbangan keuangan antara Pusat dan Daerah, adalah sebagai berikut :

Pertama, berkenaan dengan obyek atau sumber pendapatan itu sendiri. Sebab berdasarkan ketentuan yang diatur dalam undang-undang perimbangan keuangan itu, yang dibagihasilkan adalah berasal dari SDA alami yang terdapat pada masing-

\footnotetext{
${ }^{14}$ Syamsuddin Haris dalam Alfitra Salamm dan Kurniawati Hastuti (editor), Ibid., hlm. 39.

${ }^{15}$ Ibid., hlm. $39-46$.
} 
masing daerah, yaitu seperti minyak dan gas bumi, hasil hutan (IHPH/IHH, PSDH), pertambangan umum (landrent, royalty pertambangan umum), dan dari sektor perikanan (pungutan pengusahaan perikanan).

Jika diidentifikasi dana bagi hasil sumber daya alam tersebut, pada umumnya merupakan sumber daya alam yang sejak semula telah tersedia di bumi Indonesia (khususnya pada beberapa daerah) yang merupakan kekayaan alam Indonesia yang dianugerahi oleh Tuhan. Namun kekayaan alam tersebut sifatnya tidaklah permanen atau abadi, karena jika dieksploitasi secara terus menerus seperti minyak dan gas bumi dan pertambangan umum, maka pada akhirnya akan semakin menipis dan seterusnya akan habis dari muka bumi Indonesia dan tidak dapat diperbaharui lagi (unrenewable). ${ }^{16}$ Dengan demikian pada suatu masa potensi sumber daya alam ini tidak lagi dapat diharapkan sebagai sumber pendapatan baik bagi pemerintah pusat maupun bagi pemerintah daerah.

Sementara itu hasil hutan meskipun dapat diperbaharui melalui program reboisasi, namun akan memerlukan investasi yang cukup besar dengan jangka waktu yang juga cukup panjang. Sedangkan di dalam praktek sehari-hari tidak jarang pula eksploitasi hasil hutan seperti penebangan pohon-pohon kayu hutan itu selalu didasarkan pada motif ekonomis semata, yaitu mengangkut hasil hutan dan mengolahnya tanpa diikuti dengan penanaman kembali secara terencana. Di sektor perikanan, kebanyakan usaha perikanan itu adalah lebih berorientasi menangkap ikan-ikan di laut dengan armada kapal-kapal atau boat-boat penangkapan ikan.

Kedua, sumber dana bagi hasil lainnya yang diatur oleh undang-undang perimbangan keuangan di atas adalah bersumber dari bagi hasil beberapa pajak negara yang terbatas pada PBB, BPHTB dan Pajak penghasilan pribadi atau perorangan.

Sementara itu masih banyak lagi jenis-jenis pajak negara yang dipungut di daerah-daerah yang seluruh hasilnya menjadi milik pemerintah pusat tanpa ada pembagian bagi daerah-daerah penghasil pajak-pajak negara tersebut. Seperti pajak

\footnotetext{
${ }^{16}$ Menurut Husin Ceote sumber daya alam yang tidak dapat diperbaharui lagi atau yang tidak dapat pulih lagi sediakala mempunyai sifat bahwa fisik yang tersedia tetap dan tidak diperbaharui atau diolah kembali. Untuk terjadinya sumber daya alam jenis ini diperlukan waktu ribuan tahun. Mineral, batubara, minyak bumi, batu-batuan termasuk dalam katagori ini. Semua faktor produksi tersebut di atas dapat dicarikan penggantinya, tetapi dalam jangka waktu yang cukup lama, sehingga kita tidak dapat mengharapkan adanya tambahan volume secara fisik dalam jangka waktu yang cepat. Lihat Husin Ceote, "Pengelolaan Sumber Daya Alam dan Lingkungan di Era otonomi Daerah dalam Pembangunan yang Berkelanjutan”, dalam Jurnal PASKAL (Pusat Kajian Strategis Kepentingan Nasional), Jakarta, Volume I Nomor 4, Nopember 2002, hlm. 24.
} 
penghasilan perusahaan atau badan hukum, pajak pertambahan nilai, pajak barang mewah, bea materai, cukai, dan lain sebagainya. Kesemua jenis pajak-pajak ini mendatangkan pemasukan yang cukup besar bagi pemerintah pusat, sementara daerah-daerah tidak dapat menikmati hasil pungutan pajak-pajak itu yang justru obyek pungutannya berada di daerah.

\section{Kebijakan Pengaturan Perimbangan Keuangan antara Pemerintah Pusat dan Daerah Menurut UU Nomor 33 Tahun 2004}

Lima bulan setelah ditandatanganinya UU Nomor 25 Tahun 1999 oleh Presiden Bacharuddin Jusuf Habibie terjadilah amandemen terhadap UUD 1945. Terkait dengan proses amandemen konstitusi Negara ini, maka landasan yuridis bagi pengelolaan jalannya roda pemerintahan dan kemasyarakatan yang masih berdasarkan kepada ketentuan yang terdapat di dalam UUD 1945 naskah yang lama sudah tentu tidak sesuai lagi dengan semangat amandemen UUD 1945 dan harus mengalami perubahan selaras dengan amandemen itu sendiri.

Beberapa hal terpenting dari amandemen UUD 1945 itu adalah penegasan pemerintahan daerah dijalankan dengan prinsip otonomi yang seluas-luasnya kecuali urusan pemerintahan yang oleh undang-undang ditentukan sebagai urusan pemerintah pusat sebagaimana ditegaskan oleh Pasal 18 ayat (5) UUD 1945 (hasil amandemen kedua tahun 2000). Sehingga dengan demikian kewenangan untuk menjalankan urusan pemerintahan daerah berdasarkan asas otonomi semakin memberikan peluang bagi masyarakat daerah untuk melaksanakan otonomi daerahnya dengan tujuan peningkatan kesejahteraan masyarakat daerah itu sendiri. Selain itu dalam masalah keuangan, UUD 1945 pasca amandemen pun menegaskan bahwa hubungan keuangan, pelayanan umum, pemanfaatan sumber daya alam dan sumber daya lainnya antara pemerintah pusat dengan pemerintah daerah harus diatur dan dilaksanakan secara adil dan selaras berdasarkan undang-undang seperti ditegaskan oleh Pasal 18 A ayat (2) UUD 1945 (hasil amandemen kedua tahun 2000).

Ketentuan yang terdapat di dalam UUD 1945 pasca amandemen di atas, maka eksistensi UU Nomor 22 Tahun 1999 dan UU Nomor 25 Tahun 1999 pun perlu diperbaharui dengan semangat amandemen UUD 1945, karena berbagai ketentuan yang terdapat di dalam kedua undang-undang tersebut secara paradigmatig konstitusional tidak lagi sesuai dengan semangat otonomi yang dikembangkan oleh UUD 1945 hasil amandemen. Apalagi misalnya setelah keluarnya UU Nomor 22 
Tahun 1999 telah keluar pula 2 (dua) buah undang-undang pemerintahan yang bersifat khusus untuk menjalankan ketentuan yang terdapat pada Pasal 18 B UUD 1945 (hasil amandemen kedua tahun 2000) yang menyebutkan Negara mengakui dan menghormati satuan-satuan pemerintahan daerah yang bersifat khusus atau bersifat istimewa yang diatur dengan undang-undang.

Kedua undang-undang tersebut adalah UU Nomor 18 Tahun 2001 tentang Otonomi Khusus Bagi Propinsi Daerah Istimewa Aceh Sebagai Propinsi Nanggroe Aceh Darussalam dan UU Nomor 20 Tahun 2001 tentang Otonomi Khusus Papua. Di dalam kedua undang-undang ini selain diatur tentang sistem pemerintahan daerah yang agak berbeda dengan pengaturan di dalam UU Nomor 22 Tahun 1999, juga perbedaan lainnya adalah pengaturan tentang perimbangan keuangan antara pemerintah pusat dengan kedua pemerintah tersebut yakni Propinsi Nanggroe Aceh Darussalam (NAD) dan Propinsi Papua.

Di dalam UU Nomor 18 Tahun 2001 diatur perimbangan keuangan itu yang diterima Propinsi Nanggroe Aceh Darussalam (selanjutnya disingkat dengan Propinsi NAD) sebagai berikut : Bagi Hasil PBB, BPHTB PPh orang pribadi, dan bagi hasil sumber daya alam sektor kehutanan, perikanan, pertambangan umum dan pertambangan minyak bumi dan gas, pada dasarnya adalah sama dengan Daerah-daerah lainnya seperti yang diatur dalam UU Nomor 25 Tahun 1999 dan UU Nomor 17 Tahun 2000 tentang Perubahan Ketiga UU Nomor 7 Tahun 1983 tentang Pajak Penghasilan, sebagaimana telah diuraikan diatas. Namun terkait dengan penerimaan dalam rangka otonomi khusus bagi Propinsi NAD ini berupa tambahan penerimaan dari hasil sumber daya alam diwilayah Propinsi NAD setelah dikurangi pajak, yaitu sebesar 55 \% untuk pertambangan minyak bumi dan sebesar $40 \%$ untuk pertambangan gas alam yang berlaku selama 8 (delapan) tahun, dimana sejak mulai tahun ke sembilan, pemberian tambahan penerimaan ini dikurangi menjadi $35 \%$ untuk pertambangan minyak bumi dan $20 \%$ untuk pertmbangan gas alam, ${ }^{17}$ merupakan sumber penerimaan dari perimbangan keuangan yang tidak diterima daerah-daerah lainnya.

Sedangkan pengaturan perimbangan keuangan di dalam UU Nomor 21 Tahun 2001, kepada Pemerintah Propinsi Papua dan Kabupaten/Kota yang terdapat dalam

${ }^{17}$ Lihat ketentuan Pasal 4 ayat (4) dan ayat (5) UU Nomor 18 Tahun 2001 tentang Otonomi Khusus Bagi Propinsi Daerah Istimewa Aceh Sebagai Propinsi Nanggroe Aceh Darussalam. Tambahan penerimaan dari hasil sumber daya alam ini hanya berlaku bagi Propinsi NAD, dan tidak terdapat pada propinsi-propinsi lainnya meskipun mempunyai sumber daya alam yang sama. 
lingkungan wilayah Propinsi Papua diserahkan : Bagi Hasil PBB, BPHTB PPh orang pribadi, dan bagi hasil sumber daya alam sektor kehutanan, perikanan, dan pertambangan umum, pada dasarnya adalah sama dengan Daerah-daerah lainnya seperti yang diatur dalam UU Nomor 25 Tahun 1999 dan UU Nomor 17 Tahun 2000 tentang Perubahan Ketiga UU Nomor 7 Tahun 1983 tentang Pajak Penghasilan, sebagaimana telah diuraikan. Namun bagi hasil dari sumber daya alam lainnya seperti pertambangan minyak bumi dan gas alam, dibagihasilkan untuk pemerintah Propinsi Papua/Kabupaten/Kota adalah masing-masing sebesar 70 \% yang berlaku selama 25 tahun, sedangkan sejak mulai tahun ke 26 dan seterusnya penerimaan dalam rangka otonomi khusus menjadi 50 \% untuk kedua sektor pertambangan tersebut. ${ }^{18}$

Selain bagi hasil seperti disebutkan di atas, dalam rangka pelaksanaan otonomi khusus, bagi Papua diberikan penerimaan khusus yang besarnya setara dengan 2 $\%$ dari DAU Nasional yang terutama ditujukan untuk pembiayaan pendidikan dan kesehatan, yang berlaku selama 20 tahun $^{19}$ dan dana tambahan dalam rangka pelaksanaan otonomi khusus, yang besarnya ditetapkan antara Pemerintah dengan DPR berdasarkan usulan Propinsi Papua pada setiap tahun anggaran yang terutama ditujukan untuk pembiayaan pembangunan infra struktur. Dana tambahan penerimaan bagi Propinsi Papua ini, hanya berlaku bagi Propinsi Papua dan tidak terdapat pada daerah-daerah propinsi lainnya. ${ }^{20}$

Berdasarkan hal-hal di atas, kiranya perlu disesuaikan berbagai ketentuan perundang-undangan yang mengatur tentang pemerintahan daerah dan hubungan/ perimbangan keuangan yang baru sesuai dengan perkembangan amandemen UUD 1945 dan lahirnya kedua undang-undang otonomi khusus tersebut di atas. Sehingga akhirnya pada tanggal 15 Oktober 2004 ditetapkanlah UU Nomor 32 Tahun 2004 tentang Pemerintahan Daerah dan UU Nomor 33 Tahun 2004 tentang Perimbangan Keuangan antara Pemerintah Pusat dan Pemerintahan Daerah yang kemudian diikuti dengan ditetapkannya PP Nomor 55 Tahun 2005 tentang Dana Perimbangan.

\footnotetext{
${ }^{18}$ Lihat ketentuan Pasal 34 ayat (3), ayat (4), dan ayat (5) UU Nomor 21 Tahun 2001 tentang Otonomi Khusus bagi Propinsi Papua.

${ }^{19}$ Lihat ketentuan Pasal 34 ayat (3) huruf e, dan ayat (6) UU Nomor 21 Tahun 2001.

${ }^{20}$ Kecuali bagi Pemerintah Aceh yang berdasarkan UU Nomor 11 Tahun 2006 tentang Pemerintahan Aceh mendapat alokasi dana otonomi khusus yang sama persentasenya dengan Propinsi Papua ini, namun bagi pemerintahan Aceh peruntukannya digunakan untuk membiayai pembangunan dan pemeliharaan infra struktur, pemberdayaan ekonomi rakyat, pengentasan kemiskinan, serta pendanaan pendidikan, sosial dan kesehatan. Jadi lebih luas penggunaannya dibandingkan dengan Propinsi Papua.
} 
Adapun rincian sumber penerimaan daerah dari hasil perimbangan keuangan berdasarkan UU Nomor 33 Tahun 2004 dan PP Nomor 55 Tahun 2005 tentang Dana Perimbangan adalah sebagai berikut : 1 . bagian daerah dari penerimaan pajak bumi dan bangunan dan bea perolehan hak atas tanah dan bangunan, serta pajak penghasilan Pasal 25 dan Pasal 29 wajib pajak orang pribadi dalam negeri dan $\mathrm{PPh}$ Pasal 21, yang selanjutnya dibagi menurut imbangan sebagai berikut : a. penerimaan dari pajak Bumi dan bangunan (PBB) : untuk pemerintah pusat sebesar $10 \%$ dan 90 $\%$ untuk pemerintah daerah (yang selanjutnya dibagi antara propinsi sebesar 16,2 $\%$ dan kabupaten/kota memperoleh $64,8 \%$ dengan $9 \%$ digunakan untuk upah pungutan); b. penerimaan dari bea perolehan hak atas tanah dan bangunan (BPHTB) : Untuk pemerintah pusat sebesar $20 \%$ sedangkan $80 \%$ untuk daerah (pemerintah propinsi memperoleh $16 \%$ dan pemerintah kabupaten/kota memperoleh $64 \%$ ); ${ }^{21}$ c. penerimaan dari pajak penghasilan (PPh) Pasal 25 dan Pasal 29 wajib pajak orang pribadi dalam negeri dan PPh Pasal 21, yang merupakan bagian pemerintah daerah adalah sebesar $20 \%$, di mana $60 \%$ (dari bagian daerah tersebut $20 \%$ ) diserahkan untuk menjadi bagian dari penerimaan pemerintah kabupaten dan kota, sedangkan sisanya sebesar $40 \%$ (dari $20 \%$ total bagian daerah) diberikan kepada pemerintah propinsi; 2. penerimaan dari beberapa SDA yang terdapat di daerah, yang terdiri dari a. penerimaan dari IHPH yang dihasilkan dari daerah yang bersangkutan dibagi dengan imbangan $20 \%$ untuk pemerintah pusat sedangkan sisanya $80 \%$ untuk pemerintah daerah dengan rincian bagian pemerintah propinsi sebesar $16 \%$ dan kabupaten/kota penghasil memperoleh $64 \%$; b. penerimaan dari provisi sumber daya hutan (PSDH), dimana untuk pemerintah pusat sebesar $20 \%$, sedangkan untuk pemerintah daerah sebesar $80 \%$, di mana bagian dari pemerintah daerah ini $(80 \%)$ selanjutnya akan dibagi dengan imbangan sebesar $16 \%$ untuk pemerintah propinsi, sedangkan sebesar 32 \% untuk pemerintah kabupaten/kota penghasil, dan $32 \%$ sisanya dibagikan dengan porsi yang sama untuk pemerintah kabupaten/kota lainnya yang terdapat dalam daerah propinsi yang bersangkutan; c. penerimaan kehutanan yang berasal dari dana reboisasi dibagi dengan imbangan sebesar $60 \%$ untuk pemerintah propinsi yang digunakan untuk rehabilitasi hutan dan lahan secara nasional, sedangkan sisanya sebesar $40 \%$ untuk pemerintah kabupaten dan

\footnotetext{
${ }^{21}$ Setelah keluarnya UU Nomor 27 Tahun 2009 tentang Pajak Daerah dan Retribusi Daerah, maka kedua jenis penerimaan negara (PBB dan BPHTB) yang sebagian besar hasilnya diserahkan kembali kedaerah kini menjadi salah satu sumber pajak daerah untuk daerah Kabupaten dan Kota dan mulai berlaku sejak tanggal 1 Januari 2011.
} 
kota guna kegiatan rehabilitasi hutan dan lahan di kabupaten/kota penghasil; d. penerimaan dari iuran tetap pertambangan umum (landrent) yang dihasilkan dari wilayah daerah yang bersangkutan dibagi dengan imbangan sebesar $20 \%$ untuk pemerintah pusat dan $80 \%$ buat pemerintah daerah dengan rincian pemerintah propinsi memperoleh bagian $16 \%$ sedangkan kabupaten/kota penghasil akan memperoleh sebesar $64 \%$; e. penerimaan dari iuran eksplorasi dan iuran eksploitasi pertambangan umum (royalty pertambangan umum) : sebesar $20 \%$ untuk pemerintah pusat dan untuk pemerintah daerah sebesar $80 \%$ yang akan dibagi dengan rincian $16 \%$ untuk pemerintah propinsi dan $32 \%$ untuk pemerintah kabupaten/kota penghasil, sedangkan sisanya 32 \% lagi dibagi rata untuk pemerintah kabupaten/kota lainnya di dalam wilayah propinsi yang bersangkutan; f. penerimaan dari sektor perikanan yang terdiri dari hasil pungutan pengusahaan perikanan, dan penerimaan pungutan hasil perikanan, dibagi antara $20 \%$ untuk pemerintah pusat dan sisanya $80 \%$ dibagikan secara merata atau dengan porsi yang sama besar kepada seluruh pemerintah kabupaten/kota di Indonesia; g. penerimaan dari hasil pertambangan minyak bumi (setelah dikurangi komponen pajak dan pungutan lainnya sebagaimana ditentukan peraturan perundang-undangan), dibagi antara pemerintah pusat yang memperoleh 84,5\% dengan sisanya 15,5\% untuk pemerintah daerah yang kemudian dibagi lagi masing-masing untuk pemerintah propinsi sebesar $3 \%$, dan $6 \%$ untuk pemerintah kabupaten/kota penghasil serta 6 $\%$ lagi untuk pemerintah kabupaten/kota lainnya dalam wilayah propinsi yang sama. Sedangkan sisanya sebesar 0,5\% dibagi dengan rincian : 0,1 \% diserahkan untuk pemerintah propinsi, 0,2 \% untuk pemerintah kabupaten/kota penghasil, dan sisanya 0,2 \% dibagi untuk seluruh kabupaten/kota lainnya yang berada dalam propinsi yang bersangkuta; h. penerimaan dari pertambangan gas alam atau gas bumi (setelah dikurangi komponen pajak), dibagi untuk 69,5\% buat pemerintah pusat dan 30,5\% buat pemerintah daerah, yang kemudian didistribusikan untuk pemerintah propinsi $6 \%$, untuk pemerintah kabupaten/kota penghasil mendapatkan $12 \%$ dan sisanya12\% lagi dibagi rata untuk pemerintah kabupaten/ kota lainnya dalam wilayah propinsi yang sama). Sedangkan pembagian 0,5\% sisanya dibagi antara 0,17 \% untuk pemerintah propinsi yang bersangkutan, dan 0,33 \% dibagikan secara merata untuk seluruh pemerintah kabupaten/kota di dalam propinsi; dan i. penerimaan dari pertambahan panas bumi yang dihasilkan dari wilayah daerah yang bersangkutan yang merupakan penerimaan negara bukan 
pajak (PNBP) yang terdiri atas setoran bagian pemerintah dan iuran tetap dan iuran produksi, dibagi dengan imbangan $20 \%$ untuk pemerintah pusat dan sisanya sebesar $80 \%$ untuk pemerintah daerah, yang selanjutnya dibagi dengan imbangan $16 \%$ untuk pemerintah propinsi, $32 \%$ untuk pemerintah kabupaten/kota penghasil dan sisanya $32 \%$ dibagikan dengan porsi yang sama besar untuk semua pemerintah kabupaten/kota di dalam propinsi yang bersangkutan.

Dari hal-hal tersebut di atas yang berdasarkan ketentuan yang terdapat di dalam UU Nomor 33 Tahun 2004 dan PP Nomor 55 Tahun 2005 tentang Dana Perimbangan, pada prinsipnya tidak mengalami perubahan yang mendasar bila dibandingkan dengan ketentuan perimbangan keuangan yang diatur dalam UU Nomor 25 Tahun 1999. Hanya saja terjadi pergeseran persentase bagi hasil antara pemerintah pusat dengan pemerintah daerah, dan antarpemerintah propinsi dengan pemerintah kabupaten/kota di dalam wilayah propinsi yang bersangkutan. Selain itu yang cukup mengembirakan adalah dimasukkannya dana bagi hasil pajak penghasilan (PPh) Pasal 25 dan Pasal 29 wajib pajak orang pribadi dalam negeri dan PPh Pasal 21 dalam undang-undang perimbangan yang terakhir ini, dimana sebelumnya bagi hasil pajak penghasilan ini hanya dicantumkan di dalam UU PPh yang merupakan murni pajak pemerintah pusat. Sehingga akan hilang kesan bahwa pemerintah pusat dengan kebijakannya melalui undang-undang perpajakan pusat memberikan bantuan berupa bagi hasil pajak penghasilan yang dipungut oleh pemerintah pusat kepada pemerintah daerah. Dimasukkannya dana bagi hasil pajak penghasilan ini dalam undang-undang perimbangan akan semakin memperkuat otonomi daerah dari sisi pandang hubungan perimbangan keuangan antara pusat dan daerah.

Pada tanggal 1 Agustus 2006 disahkanlah UU Nomor 11 Tahun 2006 tentang Pemerintahan Aceh yang mengatur tentang jalannya pemerintahan khusus Aceh yang memiliki perbedaan yang cukup besar bila dibandingkan dengan pemerintahan daerah lainnya di Indonesia. Di dalam undang-undang ini pula diatur masalah sumber-sumber penerimaan Pemerintah Aceh dan kabupaten/kota yang terdapat dalam lingkungan propinsi Aceh, yang terbagi atas sumber pendapatan asli daerah (PAD) yang sesungguhnya tidak mempunyai perbedaan dengan yang diatur dalam UU Nomor 32 dan 33 Tahun 2004, hanya saja sebagai salah satu sumber PAD yang berbeda dengan daerah lainnya adalah terdapatnya zakat sebagai salah satu penerimaan PAD Aceh dan pemerintahan kabupaten/kota dilingkungan propinsi Aceh. 
Khusus tentang pengaturan perimbangan keuangan antara pemerintah pusat dengan pemerintahan Aceh, terdapat beberapa persamaan dan perbedaan dengan UU Nomor 33 Tahun 2004. Persamaannya adalah bagi hasil dari sektor kehutanan (80\% untuk daerah Aceh), perikanan (80 \% untuk daerah Aceh), pertambangan umum (80 \% untuk daerah Aceh), dan pertambangan panas bumi (80 \% untuk daerah Aceh), sama pengaturannya dengan daerah-daerah lainnya seperti diatur dalam UU Nomor 33 Tahun 2005. Adapun perbedaan yang terdapat di dalam UU Nomor 11 Tahun 2006 adalah bagi hasil dari pertambangan minyak bumi dimana Propinsi Aceh mendapat $15 \%$, sementara itu bagi hasil sektor ini menurut UU Nomor 33 Tahun 2004 adalah untuk daerah sebesar 15,5\%, dan penerimaan dari pertambangan gas bumi daerah Aceh memperoleh 15 \% sementara itu berdasarkan UU Nomor 33 Tahun 2004 adalah 30,5 \%. Namun dilain pihak selain dana bagi hasil ini, pemerintah Aceh mendapat tambahan dana bagi hasil minyak dan gas bumi yang merupakan bagian dari penerimaan Pemerintah Aceh yaitu bagian dari pertambangan minyak sebesar $55 \%$ dan bagian dari pertambangan gas bumi sebesar $40 \%$, dimana penggunaannya paling sedikit $30 \%$ dialokasikan untuk membiayai pendidikan di Aceh dan paling banyak $70 \%$ dialokasikan untuk membiayai program pembangunan yang disepakati bersama anara Pemerintah Aceh dengan pemerintah kabupaten/kota yang terdapat dalam wilayah Aceh, yang pelaksanaannya dilakukan oleh Pemerintah Aceh. ${ }^{22}$

Selain perbedaan seperti digambarkan di atas, perbedaan lainnya yang amat mendasar bagi Pemerintahan Aceh ini berdasarkan UU Nomor 11 Tahun 2006 bila dibandingkan dengan propinsi/daerah lainnya di Indonesia, adalah pemberian Dana Otonomi Khusus bagi pemerintahan Aceh yang merupakan penerimaan Pemerintah Aceh yang ditujukan untuk membiayai pembangunan terutama pembangunan dan pemeliharaan infra struktur, pemberdayaan ekonomi rakyat, pengentasan kemiskinan, serta pendanaan pendidikan, sosial, dan kesehatan, yang berlaku untuk jangka waktu 20 tahun dengan rincian untuk tahun pertama sampai dengan tahun kelima belas yang besarnya setara dengan $2 \%$ plafon Dana Alokasi Umum Nasional, dan untuk tahun keenam belas sampai dengan tahun kedua puluh yang besarnya setara dengan 1 \% plafon Dana Alokasi Umum Nasional seperti diatur dalam Pasal 183 ayat (1) dan (2) UU Nomor 11 Tahun 2006.

${ }^{22}$ Lihat ketentuan Pasal 182 ayat (3), ayat (4), dan ayat (5) UU Nomor 11 Tahun 2006 tentang Pemerintahan Aceh. 


\section{Penutup}

Pertama, hubungan keuangan antara Pemerintah Pusat dan Daerah dalam berbagai kebijakan peraturan perundang-undangan dapat dilihat bagaimana Pusat menyerahkan beberapa sumber-sumber pajak dan retribusi yang dimiliki pemerintah pusat yang selanjutnya menjadi sumber-sumber pendapatan asli daerah (PAD). Hal ini merupakan konsekuensi dianutnya desentralisasi pemerintahan yang melahirkan etonomi daerah untuk mengurus urusan-urusan yang telah melahirkan urusan rumah tangga daerah.

Kedua, perimbangan keuangan pasca reformasi adalah koreksi total terhadap perimbangan keuangan antara Pusat - Daerah bila dibandingkan dengan masa-masa sebelumnya. Hal ini dapat dilihat dari pengaturan perimbangan keuangan tersebut, dimana pada sebelum reformasi berdasarkan UU No. 32 Tahun 1956 tentang Perimbangan Keuangan antara Pusat dan Daerah hanya bertumpu pada penyerahan/pemberian beberapa jenis pajak Negara berdasarkan persentase tertentu dan kemudian diikuti dengan pemberian berbagai subsidi sesuai dengan pemerintah pusat. namun di dalam undang-undang perimbangan keuangan pasca reformasi seperti UU Nomor 25 Tahun 1999 dan UU Nomor 33 Tahun 2004 telah memasukkan perimbangan keuangan dalam masalah sumber daya alam yang terdapat di daerah-daerah (seperti pertambangan umum, minyak bumi dan gas kehutanan, perikanan), sehingga sumber keuangan daerah menjadi bertambah dan secara signifikan akan berpengaruh secara positif terhadap pelaksanaan otonomi daerah dari masing-masing daerah.

Perimbangan keuangan terutama setelah lahirnya UU Nomor 33 Tahun 2004 membawa implikasi semangat pelaksanaan otonomi daerah yang didasarkan semakin tidak terlalu tergantungnya daerah-daerah dari sumber keuangan daerahnya kepada pemerintah pusat seperti terjadi pada masa-masa silam. Namun perimbangan keuangan khususnya terhadap bagi hasil sumber-sumber daya alam yang dapat dikategorikan tidak dapat diperbaharui (unrenewable resourse) hanya dapat dinikmati sebagian daerah-daerah yangs ecara alamiah dianugerahi dengan kekayaan alam sedemikian tidak memp[eroleh bagi hasil. Kiranya pada masa mendatang beberapa sumber daya alam yang bersifat dapat diperbaharui secara terus menerus (renewable resourses) yang belum dijadikan bagian dari bagi hasil antara Pusat dan Daerah ini dapat direvisi, sehingga daerah-daerah yang tidak atau kurang 
potensial memiliki sumber-sumber daya alam berupa minyak bumi dan gas, pertambangan umum, hasil-hasil kehutanan dan perikanan, dapat menikmati bagi hasil dari sumber daya alam yangd apat diperbaharui ataud engan kata lain sumber daya alam olahan ekonomi seperti perkebunan, pertanian, termasuk daerah-daerah yang potensial perkembangan industrinya juga dapat menikmati bagi hasil antara pemerintah pusat dengan daerah-daerah otonomi yang memiliki potensi sumber daya olahan tersebut.

\section{Daftar Pustaka}

Akbar Nasution, Faisal, Dimensi Hukum dalam Pemerintahan Daerah, Kajian Kritis atas UU Nomor 22 Tahun 1999 dan UU Nomor 25 Tahun 1999, Pustaka Bangsa Press, Medan, 2003.

Pemerintahan Daerah dan Sumber-sumber Pendapatan Asli Daerah, PT Sof Media, Jakarta, 2009.

Andrews, Collin Mac dan Ichlasul Amal, Hubungan Pusat - Daerah dalam Pembangunan, Rajawali Pers, Jakarta, 1993.

Bird, Richard M dan Francois Vaillancourt (editor), Fiscal Decentralization in Developing Countries, Cambridge University Press, Cambridge United Kingdom, 1998.

Ceote, Husin, Pengelolaan Sumber Daya Alam dan Lingkungan di Era Otonomi Daerah dalam Pembangunan yang Berkelenjutan, dalam Jurnal Pusat Kajian Strategis Kepentingan Nasional (PASKAL) Vol. 1 Nomor 4, Nopember 2002.

Devas, Nick (editor), Keuangan Pemerintah Daerah di Indonesia, terjemahan Masri Maris, UI - Press, Jakarta, 1989.

Elmi, Bachrul, Keuangan Pemerintah Daerah Otonom di Indonesia, (Jakarta, UI Press, 2002).

Haris, Syamsuddin, et al, Indonesia di Ambang Perpecahan?, Erlangga, Jakarta, 1999.

Huda, Ni'matul, Hukum Pemerintahan Daerah, Nusa Media, Bandung, 2009

Manan, Bagir, "Hubungan Antara Pusat dan Daerah Berdasarkan Asas Desentralisasi Menurut UUD 1945", Disertasi, Universitas Padjadjaran Bandung, 1990.

P. Soeria Atmadja, Arifin, Format Hubungan Keuangan Pemerintah Pusat dan Daerah, Makalah yang disampaikan dalam diskusi "Asosiasi Pemerintah Kabupaten Seluruh Indonesia (AKASI)", tanggal 6 Agustus 2002 di Jakarta.

Keuangan Publik dalam Perspektif Hukum : Teori, Praktik, dan Kritik, Badan Penerbit Fak. Hukum UI, Jakarta, 2005.

Rauf, Maswadi, “Otonomi Daerah dan Pembangunan Nasional”, makalah dalam Seminar Otonomi dan Pembangunan Daerah, Kerja sama AIPI dengan Pemerintah Daerah Tingkat II Kabupaten Kampar, Bangkinan Riau, 1995. 
Riwu Kaho, Josef, Prospek Otonomi Daerah di Negara Republik Indonesia, Identifikasi FaktorFaktor yang Mempengaruhi Penyelenggaraan Otonomi Daerah, PT. Raja Grafindo Persada, Jakarta, 2007.

Salamm, Alfitra dan Kurniati Hastuti Dewi (editor), Dinamika Hubungan Keuangan Pusat - Daerah, Perspektif Lokal, P2P-LIPI, Jakarta, 2001.

Salamm, Alfitra, Otonomi Daerah dan Akuntabilitas Perimbangan Keuangan Pusat - Daerah, Makalah pada Workshop Desentralisasi, Demokratisasi, dan Akuntabilitas Pemerintahan Daerah, AIPI bekerja sama dengan Partnership for Governance Reform in Indonesia dan Universitas Diponegoro, Semarang, Maret 2002.

Sidik, Machfud, “Kebijakan Perimbangan Keuangan Pusat dan Daerah di Era Otonomi Daerah", Makalah yang disampaikan pada kuliah perdana Program Pascasarjana FISI-UI Jakarta, tanggal 27 Agustus 2001.

, (editor), Dana Alokasi Umum : Konsep, Hambatan, dan Prospek di era Otonomi Daerah, Buku Kompas, Jakarta, 2002.

, dalam Madyagama et al (editor), Bunga Rampai Desentralisasi Fiskal, Jakarta, Direktorat Jenderal Perimbangan Keuangan Pusat dan Daerah Departemen Keuangan RI, 2004.

, “Kebijakan Perimbangan Keuangan Pusat dan Daerah di Era Otonomi Daerah", Makalah yang disampaikan pada kuliah perdana Program Pascasarjana FISI-UI Jakarta, tanggal 27 Agustus 2001.

Stacey, Roger dan John Oliver, Public Administration; The Political Environment, (Great Britain, Mac Donald \& Evans Ltd, 1980).

Suparmoko, M., Keuangan Negara dalam Teori dan Praktek, edisi 4, BPFE, Yogyakarta, 1991. 